\title{
The Research on the Impact of China's New Budget Law of the Market Process of Local Government Bonds
}

\author{
Tao Wang ${ }^{1}$, Zhi-qi Zhu ${ }^{2,3}$, Ke Gao ${ }^{1}$, Xiao-jing Hao ${ }^{1}$ \\ ${ }^{1}$ The School of Public Finance and Taxation, Central University of Finance and Economics, Beijing, P. R. China \\ ${ }^{2}$ The School of Economics, Tianjin University of Finance and Economics, Tianjin, P. R. China \\ ${ }^{3}$ Chinese Academy of Fiscal Sciences, Beijing, P. R. China
}

Email address:

manutdwangtao@126.com (Tao Wang), zhuzhiqi12345@163.com (Zhi-qi Zhu),gkfly@126.com (Ke Gao),

Elaine_working@163.com (Xiao-jing Hao)

\section{To cite this article:}

Tao Wang, Zhi-qi Zhu, Ke Gao, Xiao-jing Hao. The Research on the Impact of China's New Budget Law of the Market Process of Local Government Bonds. Journal of Finance and Accounting. Vol. 6, No. 1, 2018, pp. 18-25. doi: 10.11648/j.jfa.20180601.13

Received: January 14, 2018; Accepted: February 2, 2018; Published: February 24, 2018

\begin{abstract}
With the implementation of the New Budget Law in 2015, the "front door" for the issuance of local government bonds has been opened and hundreds of local bonds have entered the bond market. However, whether the New Budget Law really enhances the marketability of local government bonds, this has been a common concern of all walks of life. Since there is no discount or premium on the local government bonds issued in China at present, the market-based pricing of the issue interest rate is the main index to measure the degree of marketization of local bonds. This paper firstly summarizes the relevant factors that influence the interest rate of local government bonds under the condition of marketization, and then analyzes the impact of these factors on the interest rate of local bonds around 2015 by means of empirical ways, to determine whether the degree of marketization of local bonds is affected by the New Budget Law. The results of regression analysis show that under the condition of keeping other factors unchanged, the new budget method has a significant positive correlation with the local debt issuance rate as a dummy variable, which shows that the implementation of the new budgeting law has indeed affected the issuance rate of local bonds. In the regression of local bonds issued before and after 2015, comparing local debt bond characteristics variables with local debt issuer characteristic variables, this article finds that except for local bond issuance, other variables are significant in both regression, The effect of local bond issuance on the interest rate of local bonds after the implementation of the New Budget Law becomes significantly positive. This shows that the degree of marketization of local government bonds has been somewhat enhanced after the implementation of the New Budget Law.
\end{abstract}

Keywords: Local Government Bonds, Marketization of Interest Rates, New Budget Law

\section{Introduction}

Since the Central Government issued a 4 trillion yuan stimulus package in 2008, local government debt had rapidly accumulated. Before the budget law was amended, "the local governments are not allowed to issue local government bonds," because "the local budgets at all levels have been prepared in accordance with the principle of quantity and expenditure, balance of payments," and "local governments are not allowed to issue local government bonds." Therefore, to ease the financial pressure on fulfilling their functions, local governments frequently used the financing platform to conceal the debt, the scale and risk of debt once lost control. In response, the Central Government decidedto implement the policy of "opening the front door and blocking the back door". In August 2014, the National People's Congress revised its budget law and the New Budget Law came into effect in January 2015, which clearly stipulated: "Some funds necessary for the construction investment in the budgets of provinces, autonomous regions and municipalities directly under the Central Government approved by the State Council may be raised through the issuance of local government bonds by borrowing within the limits set by the State Council." That means that the "front door" for local government debt issuance 
is properly liberalized. In the meantime, the local government is prohibited from any form of debt guarantee, blocking the "back door" of the debt. In 2014, State Department Document No. 43 clearly stipulated that local governments should bear the responsibility for repaying their debts and the Central Government did not implement the principle of salvage. As can be seen from the relevant provisions above, the Central Government hopes to strengthen the local government's budget constraint through the New Budget Law and relevant documents so that it can become an independent debtor and thus promote the marketization of local government bonds.

From the perspective of academic point of view, a part of scholars for the local government bond market is optimistic, Gu Sheng-zu, Liu Wei (2015) argue that the New Budget Law can be improved to build and perfect the market constraints, rules management, andmulti-level local government debt management system combined with administrative control [1; 2]. Sun Bo (2014) believes that boththe market and transparency are the way to standardize the development of local government debt [3]. Jia Kang (2014) thinks that government bond is a financial product with high market level, transparency and financial efficiency. It is the main debt variety that should be promoted in the development of China's financial market [4]. Yuan Zhi-hui (2015) holds that from the August 2015 Liaoning debt index and the successful issuance of the Tianjin debt in the same period, it can be seen that the marketization characteristics of local bonds are obvious [5]. However, on the other hand, many scholars also think that the prospect of local government debt market is concerned. Wang Li-ying, Sun Yi-fan, and Xu Bo-wen (2014) argue that the Central Government's implicit guarantee of local government debt is hard to be blocked and that local financial institutions provide disguised subsidies to local government debts. This will become a hindrance to the real marketization of local government bonds [6]. From the perspective of international experience, in the countries with relatively mature government bonds, such as the US and Japan, the degree of marketization of government bonds has a relatively high level, and the market provides sufficient and sound financial support for public goods (Zhang Hai-xing, 2001) [7]. It can be seen that through the construction of the legal system, the development of local government bond market and the promotion of the effectiveness of local bond pricing mechanism are the inevitable trends of the future development of local debt financing in China.

The improvement of the marketization of local bonds is conducive to the full play of the market pricing and the improvement of the efficiency of the government's debt financing. It is beneficial to standardize the behavior of local government and guard against moral hazard. It is beneficial to widen the way of government financing and alleviate the pressure of economic downside. By means of empirical analysis, this paper analyzes the market influence factors of local government bond issuing interest rate, and explores the marketization process of China's local government bonds under the background of the New Budget Law.

\section{The Theoretical Framework of Local Bond Marketability}

Since there is no discount or premium on the issuance of local government bonds in China at present, the main indicator to measure the degree of marketization of local government bonds is the influence of market factors on the interest rate of local bonds. Theoretically speaking, the market interest rate of the issuance of local government bonds is mainly affected by three factors: the macroeconomic factors, the characteristics of the bonds themselves and the characteristics of the main body of bond issuance. Specific analysis is as follows:

\subsection{Macro Factors}

When Nakashima and Saito (2009) studied the Japanese corporate bond market, they found that: macroeconomic factors have a significant impact on the credit spread of corporate bonds [8]. For the local bonds, the macro factors mainly include the level of economic development in the area where the bonds are issued and the types of monetary policies implemented by the central bank. In general, more relaxed monetary policy will lead to a more liquid market and a lower interest rate of bond issuance, so the easing of monetary policy on bond issuance rates is negative. Since there is often a nonlinear relationship between government debt and economic growth (Krugman, 1988) [9]. This implies that government debt has different values for economic development at different stages of economic development. Under market conditions, the issuance rate of government bonds is the price of bonds. As prices fluctuate around the value, different levels of economic development have different impacts on the interest rates of local bonds.

\subsection{Bonds Own Characteristics}

Han Li-yan, Cheng Cheng-li, Luo Wen and Yang Zhe-bin (2003) conclude from the data on the issuance of Beijing and Shanghai that as the size of bond issuance increases, the possibility of bond defaults becomes greater [10]. In addition, a larger scale of bond issuance will lead to a larger scale of capital market demand. Under the condition of a certain scale of capital supply in the region, the issuance rate of interest must also increase. Therefore, the size of bond issuance has a positive effect on the interest rate of local government bonds. According to the practical experience of the general bond issue market, a longer bond issuance period will result in a greater uncertainty and a higher risk, therefore, the interest rate of local government bond issuance is higher.

\subsection{The Market Characteristic Model of Local Government as Issuer}

This paper characterizes the local bond marketability of local governments as issuers through a simplified debt crisis model by Romer (2011) [11].

\subsubsection{Assumptions}

The local budget deficit is all covered by the issuance of 
debt. The total amount of debt to be issued by the local government in period $\mathrm{t}$ is $D$, which includes the historical maturity debt $D_{l}$ and the fiscal deficit $D_{t}$ in period t. Let the local government's interest factor is $I$, that is, the effective interest rate is $I-1$. Let the next government revenueis $R_{t+1}$, and $R_{t+1}=\beta R_{t}+\varepsilon_{t}$, where $\beta$ is the growth factor of exogenous financial revenue, $R_{t}$ is the financial income in period $\mathrm{t}, \varepsilon_{t}$ is a random variable subject to $N(0,1)$ normal distribution. Supposewhen the government bonds expire, all the government revenue are used to repay the debt, and at least to repay the principal. That is, if $R_{t+1}>D$, the government pays the debt held by the bondholders, if $R_{t+1}<D$, government defaults, that is, a debt crisis. To make the model more concise, this paper assumes that if the government defaults, it will reject all the debt. Investors' risk appetite is neutral. Risk-free interest rate factor $I^{*}$ is independent of government interestland bond issuance $D$. This means that local government bonds are only a small part of the bond market and can not affect the risk-free interest rate for the entire market, i.e. there is no systemic risk.

\subsubsection{Model Analysis}

From an investor's point of view, because investors are risk-neutral, the expected earnings of creditors holding government debt must be equal to risk-free income. Suppose the probability of the payment is $1-\pi$, the probability of default is $\pi$. Equilibrium:

$$
(1-\pi) * I=I^{*}
$$

After finishing you can get:

$$
\pi=I /\left(I-I^{*}\right)
$$

Figure 1 depicts the trajectory that satisfies the equation (2). When the government does not breach of contract $(\pi=0)$, $I=I^{*}$. As the probability of default increases, the interest rate provided by the government is bound to increase, so the trajectory is upward. Finally, as default probability tends to 1, Itends to infinity.

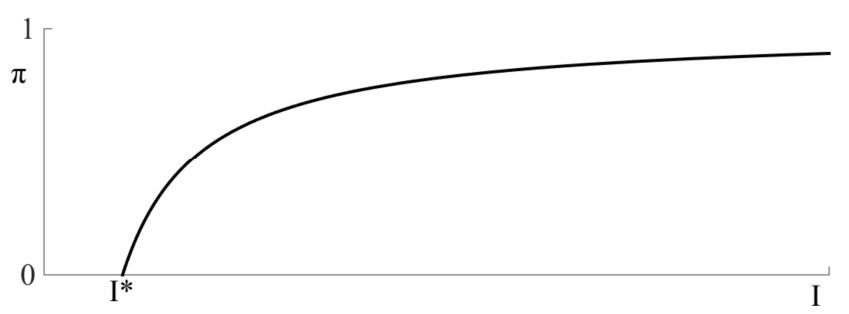

Figure 1. Government interest rates and probability of default.

From the government's point of view, since all the income in period $t+1$ is used to repay debts, whether the government defaults depends on whether the government's income in period $\mathrm{t}+1$ can make up for its arrears. The government defaultsif and only if the government's $R_{t+1}$ incomes less than the government's due debt $D$, so the probability of government defaults is the probability of $R_{t+1}$ being less than $D$, that is, $\pi=P\left(R_{t+1}<D\right)=P\left(\beta R_{t}+\varepsilon_{t}<D\right)=$ $P\left(\varepsilon_{t}<D-\beta R_{t}\right)$. Due to $\varepsilon_{t} \sim N(0,1)$, the probability distribution function is $F(\cdot)$, than the probability of debt default can be written as:

$$
\pi=F\left(D-\beta R_{t}\right)
$$

The expressions that can be solved by equations (2) and (3):

$$
I=I^{*} /\left(1-F\left(D-\beta R_{t}\right)\right.
$$

Since the government's debt $D$ consists of the t-period deficit and the historical maturity debt, which $D_{t}$ is equal to the previous period's revenue $R_{t}$ minus the prior period expenditure $E_{t}$. As follows:

$$
\mathrm{D}=D_{1}+D_{2}=D_{1}-R_{t}+E_{t}
$$

Taking (5) into (4), we can get the investor's response function to the government interest rate:

$$
I=I^{*} /\left(1-F\left(D_{1}-E_{t}+(1+\beta) R_{t}\right)\right.
$$

From (6), it can be seen that due to $F(\cdot)$ monotonous increases, under market conditions, the government interest rate has a positive correlation with the market risk-free interest rate factor, the historical debt, and the fiscal expenditure; has a negative correlation with the financial income.

\section{Data Description and Research Design}

\subsection{Data Sources}

The sample is a local government bond issued on the bond market from 2009 to November 5, 2015, excluding bonds issued on behalf of the Ministry of Finance. The data source is the Guotai Junan Bonds database. During the entire sample period, 570 local government bonds were issued by local governments in all regions, of which 466 were issued after 2015; atotal of 403.8 billion government bonds were issued before 2015, 2.24 trillion yuan were issued in all regions sincethe New Budget Lawwas implemented to November $5^{\text {th }}$. The financial revenue and expenditure of each province and the per capita GDP data are from the calendar year China Statistical Yearbook. The daily risk-free rate data comes from the Resset financial database. Seven-day interbank market pledged repo rate data comesfrom the Shanghai Stock Exchange website.

\subsection{Research Design and Variable Declarations}

This article is divided into two stages to study the impact of the implementation of the New Budget Law on the market-oriented characteristics of local government bonds. The first stage is the implementation of the New Budget Law as a dummy variable to test its overall impact on the interest rates of local government bonds; the second stage is to analyze the changes of the market-based level of local government bonds before and after the implementation of the New Budget Law.

Since there is no discount or premium issue of the local government bonds issued in China at present, this paper constructs the linear regression equation based on the research of Fisher (1959) [12] and Yang (2015) [13], to analyze the impact of various factors on the coupon rate Intetest In $_{i}$ of the 
i-th local government bond:

$$
\text { Intetest }_{i}=\alpha+\beta_{1} \text { Riskfree }_{\text {Rate }_{i}}+\beta_{2} \text { Bond }_{i}+\beta_{3} \text { Issuer }_{i}+\beta_{4} \text { New }_{\text {law }}+\beta_{5} X+\varepsilon_{i}
$$

Among them, Riskfree Rate $_{i}$ is the risk-free interest rate on the day of the issuance of the i-th bond, which derived fromReith Financial Database; Bond $i$ is the bond characteristics of the $\mathrm{i}$-th bond; Issuer $r_{i}$ is the issuer characteristics of the i-th bond. Since the issuance of local bonds is coordinated by the governments of provinces, autonomous regions and municipalities directly under the
Central Government, in order to ensure the comparability of data, this paper classifies the issuer characteristics of bonds issued by sub-provincial cities into the features of the province where they are located.New law $_{\text {isa }}$ dummy variable for the implementation of the New Budget Law. The control variable is $\mathrm{X}$. The specific conditions of each variable are shown in Table 1.

Table 1. Variable descriptions.

\begin{tabular}{|c|c|c|c|c|}
\hline \multicolumn{2}{|l|}{ Variable } & Variable name & Variable description & Expected symbol \\
\hline \multicolumn{5}{|c|}{ Dependent Variable } \\
\hline \multicolumn{2}{|l|}{ Coupons issued } & Interest & The issuing price of local government bonds & \\
\hline \multicolumn{5}{|c|}{ Independent Variable } \\
\hline \multicolumn{2}{|c|}{ New Budget Law } & New_law & $\begin{array}{l}\text { The dummy variable of whether the New Budget Law be implemented } \\
\text { or not at the time of issuance, Implemented as } 1 \text {, otherwise } 0\end{array}$ & \\
\hline \multirow{3}{*}{$\begin{array}{l}\text { Bond } \\
\text { characteristics }\end{array}$} & Issuance amount & Volume & The actual amount of bonds issued & Positive \\
\hline & Issue period & Maturity & Bond issue period & Positive \\
\hline & Last year's financial revenue & Revenue & The previous year's financial revenue in the area of issuer & Negative \\
\hline \multirow{2}{*}{$\begin{array}{l}\text { Issuer } \\
\text { characteristics } \\
\text { of bonds }\end{array}$} & $\begin{array}{l}\text { Last year's financial } \\
\text { expenditure }\end{array}$ & Expenditure & The previous year's financialexpenditure in the area of issuer & Positive \\
\hline & Debt burden & Debt_Ratio & $\begin{array}{l}\text { The ratio of debt due to local governments in June } 2013 \text { to the } 2013 \\
\text { GDP of the region }\end{array}$ & Positive \\
\hline \multirow{3}{*}{$\begin{array}{l}\text { Control } \\
\text { variables }\end{array}$} & Risk-free rate & Riskfree_Rate & Risk-free interest rates on the date of the bond issue & Positive \\
\hline & Economic level & $\begin{array}{l}\text { Per Capita } \\
\text { GDP }\end{array}$ & $\begin{array}{l}\text { Last year's per capita GDP as the proxy for economic development level } \\
\text { variable }\end{array}$ & \\
\hline & Monetary Policy & Repo7d & $\begin{array}{l}\text { Interbank market pledged repo rate in the } 7 \text { day period of the month of } \\
\text { the bond issuance }\end{array}$ & Positive \\
\hline
\end{tabular}

The variables reflecting the characteristics of the bonds are the bond issuance amount Volumeand the issue periodMaturity. In general, a larger bond issuance amount will lead to a higher interest rate at the time of issuance, so the expected sign is positive; a longer bond issuance period will result in a greater risk and a higher interest rate, so the expected sign is positive.

The main characteristics of the issuer include: the previous year's fiscal revenue of the local governments that issued the bondsRevenue; the financial expenditures of the previous yearExpenditure; and the ratio of the debts of local governments with direct repayment obligations, which is announced by the Audit Commission in June 2013, to the 2013 GDP-Debt_Ratio, as the proxy variable of government debt burden. According to the theoretical model, the previous year's fiscal revenue is negatively related to the interest rate of local government bonds, and the expected symbol is negative. The previous year's fiscal expenditure is positively related to the interest rate of local government bond issuance, and the expected symbol is positive. The level of government debt is positively related to the interest rate of local government bond issuance, and the expected symbol is positive.

Control variables are used to control macroeconomic factors and risk-free rate factors, including risk-free ratesRisk free Rate, the per capita GDP of the region last yearPer Capita GDP, theinterbank market pledged repo rate in the 7 day period of the month of the bond issuanceRepo $7 \mathrm{~d}$. According to the model, a higher risk-free rate will lead to a higher interest rate of local government bonds, so the expected sign is also positive. Repo $7 d$ as a proxy for monetary policy, says the central bank's monetary policy, a lowerRepo7d will cause a more relaxed monetary policy and a lower interest rate on bond issuance, so the expected sign is positive. Per capita GDP is used to control the economic development in different localities.

\section{Empirical Results and Analysis}

\subsection{Descriptive Statistics}

The data characteristics of the main indicators are shown in the following table:

Table 2. Data characteristics.

\begin{tabular}{llllll}
\hline Variable & Sample number & Sample mean & Sample variance & Sample minimum & Sample maximum \\
\hline Interest & 570 & 3.23 & 0.53 & 1.60 & 4.33 \\
Maturity & 570 & 6.07 & 2.59 & 1.00 & 10.00 \\
volume & 570 & 46.36 & 39.25 & 0.80 & 202.50 \\
Revenue & 570 & 2716.23 & 1927.25 & 71.57 & 8065.08 \\
\hline
\end{tabular}




\begin{tabular}{llllll}
\hline Variable & Sample number & Sample mean & Sample variance & Sample minimum & Sample maximum \\
\hline Expenditure & 570 & 4293.00 & 2058.41 & 324.61 & 9152.64 \\
Debt_Ratio & 570 & 0.19 & 0.09 & 0.08 & 0.58 \\
Per Capita GDP & 570 & 51328.36 & 21560.63 & 8824.00 & 105231.30 \\
Risk free_Rate & 570 & 0.0000854 & 0.0000202 & 0.000033 & 0.000155 \\
Repo7d & 570 & 2.468167 & 0.5518219 & 0.94 & 4.521335 \\
\hline
\end{tabular}

As can be seen from the above table, except for bonds issued in the name of the Ministry of Finance, 570 local government bonds were issued in China from 2009 to November 5, 2015. The interest rate was between $1.6 \%$ and $4.33 \%$, the average value was $3.23 \%$. The time limit for issuance ranged from 1 to 10 years, with an average of about 6 years. The average issuance of each bond was 4.636 billion yuan.

\subsection{Visual Evidence of Changes in the Issuance of Local Government Bonds}

Comparing the data of local government debt issuance before and after 2015 with the following table:

Table 3. The comparison of data characteristics.

\begin{tabular}{|c|c|c|c|c|c|c|c|c|}
\hline & 2009-20 & & & & 2015 & & & \\
\hline Variable & Interest & Maturity & volume & Repo7d & Interest & Maturity & volume & Repo $7 d$ \\
\hline Sample number & 104 & 104 & 104 & 104 & 466 & 466 & 466 & 466 \\
\hline Mean & 2.86 & 4.79 & 38.83 & 2.45 & 3.31 & 6.36 & 48.04 & 2.47 \\
\hline Variance & 1.05 & 2.28 & 19.66 & 1.29 & 0.24 & 2.57 & 42.24 & 0.08 \\
\hline Minimum & 1.60 & 3.00 & 7.50 & 0.94 & 2.38 & 1.00 & 0.80 & 2.12 \\
\hline Maximum & 4.33 & 10 & 90 & 4.52 & 3.99 & 10 & 202.5 & 2.58 \\
\hline
\end{tabular}

From the perspective of the number of issuance, from 2009 to the end of 2014, as the system of legal institutions had not been established, in six years, local governments issued 104 bonds in the form of pilot policies. After the implementation of the New Budget Law, from the beginning of 2015 to November 5, 466 local government bonds were issued by local governments, much higher than before. From the point of view of issuance interest rate, the average value before 2015 had been $2.86 \%$, and some of the local bonds evenhad a lower interest rate than the Treasury yields over the same period (Yuan Zhi-hui, 2015). Since 2015, the average interest rates on issuance of local government bonds has been $3.31 \%$. In the two time periods, the mean of the interbank market reverse repo rate has only changed by $0.02 \%$. It can be seen thatabove interest rates have been raised. Compared with the previous low interest rates, the newly issued local government bonds more accurately reflect the true cost of funds. From the point of view of the amount of funds raised from the issue, the average amount of funds raised by local bonds before 2015 was 3.883 billion, down from 4.804 billion in 2015 . To sum up, it can be intuitively seen that the change of local government bond issuance before and after the implementation of the New Budget Law is very obvious.

\subsection{An Empirical Study on the Factors Affecting the Interest Rate of Local Government Bonds}

\subsubsection{Empirical Analysis of the Effect of the New Budget Law on the Interest Rate of Local Government Bonds}

To exclude the interference of unknown heteroscedasticity problems, this article uses the standard error of ordinary least squares regression, regression results in the table below.

Table 4. Regression results 1 .

\begin{tabular}{|c|c|c|c|c|}
\hline & Model (1) & Model (2) & Model (3) & Model (4) \\
\hline & Interest & Interest & Interest & Interest \\
\hline \multirow[t]{2}{*}{ New_law } & $0.183 * *$ & $0.270 * * *$ & $0.264 * * *$ & $0.227 * * *$ \\
\hline & $(2.48)$ & $(9.05)$ & $(9.29)$ & $(7.71)$ \\
\hline \multirow[t]{2}{*}{ Maturity } & $0.114 * * *$ & $0.0833 * * *$ & $0.0822 * * *$ & $0.0819 * * *$ \\
\hline & $(20.75)$ & $(25.45)$ & $(24.26)$ & $(24.61)$ \\
\hline \multirow[t]{2}{*}{ Volume } & $-0.000817 * *$ & $0.000563 * * *$ & $0.000683 * * *$ & $0.000655 * * *$ \\
\hline & $(-2.50)$ & $(2.86)$ & $(3.56)$ & $(3.40)$ \\
\hline \multirow[t]{2}{*}{ Revenue } & -0.0000269 & $-0.0000250 * *$ & $-0.0000250 * *$ & $-0.0000620 * * *$ \\
\hline & $(-1.40)$ & $(-2.35)$ & $(-2.42)$ & $(-3.96)$ \\
\hline \multirow[t]{2}{*}{ Expenditure } & $0.000106 * * *$ & $0.0000273^{* * *}$ & $0.0000257 * *$ & $0.0000533 * * *$ \\
\hline & $(5.70)$ & $(2.60)$ & $(2.46)$ & $(3.76)$ \\
\hline \multirow[t]{2}{*}{ Debt_Ratio } & $0.503 * * *$ & 0.114 & 0.0943 & 0.111 \\
\hline & $(2.77)$ & $(1.25)$ & $(1.10)$ & $(1.29)$ \\
\hline \multirow[t]{2}{*}{ Repo7d } & & $0.645 * * *$ & $0.371 * * *$ & $0.366 * * *$ \\
\hline & & $(28.12)$ & $(5.40)$ & $(5.41)$ \\
\hline Riskfree_Rate & & & $(3.16)$ & $(3.10)$ \\
\hline \multirow[t]{2}{*}{ Per_Capita_GDP } & & & & $0.00000183 * * *$ \\
\hline & & & & $(2.78)$ \\
\hline
\end{tabular}




\begin{tabular}{lllll}
\hline & Model (1) & Model (2) & Model (3) & Model (4) \\
\hline & Interest & Interest & Interest & Interest \\
\hline Constant & $1.947^{* * *}$ & $0.813^{* * *}$ & $0.829^{* * *}$ & $0.782^{* * *}$ \\
& $(20.49)$ & $(19.97)$ & $(24.33)$ & $(20.60)$ \\
$\mathrm{N}$ & 570 & 570 & 570 & 570 \\
$\mathrm{R}^{2}$ & 0.519 & 0.875 & 0.882 & 0.885 \\
\hline
\end{tabular}

Note: The values in brackets are t- statistics. *,**, and *** indicate that the coefficients are significantly different from zero at $10 \%, 5 \%$, and $1 \%$, respectively.

Comparing the results of models (1) to (4), it can be seen that the regression coefficients become more significant and the fitting effect of the model is better after adding the control variables used to control the macro-factors and the risk-free interest rate. Since the coefficients of the three control variables are significant at the $1 \%$ level, this article analyzes the regression results from the model (4) with three control variables.

From model (4), it can be seen that the coefficient ofNew lawis significantly different from zero at the level of $1 \%$ and the coefficient is positive. This shows that the New Budget Law has a significant positive impact on the issuance rate of local government bonds, and the cost of local government debt financing has increased after the implementation of the New Budget Law. This shows that the interest rate of bonds issued by local governments before the implementation of the New
Budget Law may indeed be affected by policy-related factors such as the implicit guarantee of the Central Government, resulting in lower interest rates of bond issuance than those issued by local governments as independent issuers.

\subsubsection{Empirical Analysis of the Characteristics of the Bond and Issuer on the Interest Rate of Bond}

This article conducts a regression analysis of local bonds issued before and after 2015, in the meantime, also uses the standard deviation of the ordinary least squares method to eliminate the influence of unknown forms of heteroskedasticity. The model (5) returns all 570 local government bonds, Model (6) regresses the bonds issued before 2015. Model (7) returns the bonds issued after the implementation of the New Budget Law. The results are as follows:

Table 5. Regression results 2.

\begin{tabular}{|c|c|c|c|c|}
\hline Variable & 2009 2015 Model（5） & Before 2015 Model（6） & After 2015 Model（7） & Expected symbol \\
\hline & Interest & Interest & Interest & \\
\hline Maturity & $\begin{array}{l}0.0871 * * * \\
(24.61)\end{array}$ & $\begin{array}{l}0.137 * * * \\
(7.75)\end{array}$ & $\begin{array}{l}0.0752 * * * \\
(27.88)\end{array}$ & Positive \\
\hline Volume & $\begin{array}{l}0.000520 * * \\
(2.43)\end{array}$ & $\begin{array}{l}-0.000373 \\
(-0.34)\end{array}$ & $\begin{array}{l}0.000794 * * * \\
(4.54)\end{array}$ & Positive \\
\hline Revenue & $\begin{array}{l}-0.000143 * * * \\
(-8.49)\end{array}$ & $\begin{array}{l}-0.000237 * * * \\
(-2.85)\end{array}$ & $\begin{array}{l}-0.0000277 * * \\
(-2.23)\end{array}$ & Negative \\
\hline Debt_Ratio & $\begin{array}{l}0.223 * * \\
(2.44)\end{array}$ & $\begin{array}{l}0.367 \\
(1.41)\end{array}$ & $\begin{array}{l}0.0212 \\
(0.27)\end{array}$ & Positive \\
\hline Repo7d & $\begin{array}{l}0.332 * * * \\
(4.38)\end{array}$ & $\begin{array}{l}0.359 * * * \\
(5.01)\end{array}$ & $\begin{array}{l}0.0448 \\
(0.56)\end{array}$ & Positive \\
\hline Riskfree_Rate & $\begin{array}{l}7729.8 * * * \\
(2.84)\end{array}$ & $\begin{array}{l}4588.7 * \\
(1.81)\end{array}$ & $\begin{array}{l}-2318.0 \\
(-0.79)\end{array}$ & Positive \\
\hline _cons & $\begin{array}{l}0.786^{* * *} \\
(16.72)\end{array}$ & $\begin{array}{l}0.490 * * * \\
(4.90)\end{array}$ & $\begin{array}{l}2.839 * * * \\
(9.93)\end{array}$ & \\
\hline$N$ & 570 & 104 & 466 & \\
\hline$R^{2}$ & 0.868 & 0.949 & 0.652 & \\
\hline
\end{tabular}

Note: The values in brackets are t- statistics. $*, * *$, and $* * *$ indicate that the coefficients are significantly different from zero at $10 \%, 5 \%$, and $1 \%$, respectively.

First, this paper analyzes the characteristics of bonds in local bonds. From the regression results of models (5), (6) and (7), the bond maturities have a strong positive impact on the issue interest rates of local government bonds. This result agrees with expectation that the longer the term is, the greater the risk is, the higher the interest rate is. Therefore, it can be seen that the effect of bond maturities on the interest rates of local government bonds is in line with market-oriented characteristics.

The impact of bond issuance on the interest rates of local bonds is significant in models (5) and (7), and the parameter symbols are in line with expectations. However, in model (6), the impact of bond issuance on local bonds is negative and insignificant. This shows that local bond issuance rates are not sensitive to their circulation until the New Budget Law is implemented in 2015. In an effective market, a larger bond issuance size will lead to a higher risk of default and a higher issuance rate. Therefore, it can be seen that after the implementation of the New Budget Law, the market-oriented characteristics of local government bonds have been enhanced.

Second, this paper analyzes the characteristics of issuers of local bonds. According to the regression results of models (5), 
(6) and (7), the previous year local fiscal revenue has a significant negative impact on the interest rate of local government bonds, which is consistent with the conclusion drawn from the theoretical model. In theory, fiscal revenue is the most important indicator to measure the solvency of a local government. The stronger the solvency is, the lower the default risk is, the lower the interest rate is. Therefore, the regression of fiscal revenue shows that local governments are in line with the characteristics of marketization bond issuers.

The fiscal expenditure has a significant positive impact on the interest rates of local government bonds, which is the same as theoretical model. From a theoretical point of view, for local governments, the fiscal expenditure has a certain rigidity. The more fiscal expenditure means that the less funds it can use to repay debts, the higher the risk of local government bonds is, so that the higher the issuance of interest rate is. Therefore, the regression of fiscal expenditure shows that local governments are in line with the characteristics of marketized bond issuers.

From the regression results of model (5), the local government's debt ratio shows a significant positive correlation with the local bond issuance rate, which is the same as the result of above theoretical model. Theoretically, the historical debt ratio of local governments is an important factor that affects the interest rate of new bond issuance. The heavier debt burden will lead to the greater risk of default and the higherissuance rate. However, from the models (6) and (7), although the impacts are positive, they are not significant. There are two possible explanations for this. The first is that the debt ratio does have a positive impact on the local bond issuance rates. However, due to the limited data, this paper uses the local government's debt levels in 2013. Before 2015, the issuance of local government bonds had been a pilot issue with relatively few provinces and municipalities, making the sample too small to reflect the overall characteristics. After 2015, when local government bonds were issued, the major underwriters referred to the latest local government debt data. In comparison with the data in 2013, the major underwriters changed their relationship with each other. Model (5) is notable for the fact that the local government debt ratio in 2015 has a certain correlation with 2013, so that the sample can reflect the overall characteristics to a certain extent. The second explanation is that there is no linear correlation between them. The model (5) is obviously caused by the technical problems such as the lack of variables. With reference to the results of theoretical models and the actual experience, this article is inclined to the first possibility, but to be sure of the conclusion needs further data.

All in all, from the point of view of bond characteristics, the issuance of local government bonds can significantly affect bond interest rates after the implementation of the New Budget Law, which proves directly the enhancement of the marketability of local bonds. From the perspective of issuer characteristics, both fiscal revenue and expenditure have a significant impact on local bond issuance rates, and the impact is consistent with the theoretical expectation. In general, the implementation of the New Budget Law has strengthened the degree of marketization of local government bonds.

\section{Conclusion}

Since the economic crisis of 2008, the sustained positive fiscal policy and the backwardness of the local debt system has caused the problem of local government debt in China. In 2014, the National People's Congress revised its budget law, giving the local government the main qualifications for borrowing. At the same time, the State Council provided a large number of relevant laws and regulations and opened the "front door" for bonds issued by local governments. With the ever-increasing bond issue size, there is a general concern whether the implementation of the New Budget Law really promotes the marketization of local government bonds. This paper compares the market factors that affect the interest rate of local bonds before and after the implementation of the Budget Law through empirical methods. The main conclusion shows that, Firstly, the issuance rate of local government bonds significantly increases after the implementation of the New Budget Law, which to some extent shows that the local government bonds issued prior to the New Budget Law contain policy-related factors such as the invisible guarantee of the Central Government, thus reducing the issuance rate. After the New Budget Law, the local government becomes a relatively independent debtor, resulting in an increase in the interest rate. Secondly, the characteristics of bonds in local bonds have significant impact on the interest rates of local bonds after the implementation of the New Budget Law. In particular, the size of bond issuancehas no significant effect on the interest rate beforethe New Budget Law, but has a significant positive impact since its implementation. This shows that the degree of marketization of local government bonds has been strengthened after the implementation of the New Budget Law. Thirdly, as the main body of debt, financial revenue and expenditure have obvious influence on the interest rate of local bond issuance, which is in line with the deduction of theoretical model. This shows that the characteristics of bond issuers have a significant impact on the interest rate of their bonds, which is in line with the requirements of market-oriented conditions.

The implementation of the New Budget Law in 2015 raises the degree of marketization of local government bonds in China and the market factors have an increasing impact on the interest rate of local bond issuance. On the one hand, this is conducive to enhancing the standardization and sustainability of local government debt financing in China, preventing moral hazard, broadening government financing channels and easing downward pressure on the economy. On the other hand, it also helps to give full play to the role of market resources in allocating resources and reduces the hidden debt risks of local governments on the basis of enhancing the liquidity of local government bonds.

\section{Acknowledgements}

Thanks for the support of Central University of Finance and 
Economics Ph. D Key Supporting Topic Plan "Study on Financial Sustainability and Debt Risks of Local Governments under New Financial Standard" (Project No. 2016-PYXT03) and Central University of Finance and EconomicsGraduate Research and Innovation Fund Project "Study on the Credit Rating of Chinese Local Governments".

\section{References}

[1] Gu Sheng-zu, Liu Wei, Zhuang Qin-qin. (2015). New "Budget Law" and Prevention and Control of Debt Risks of Local Governments. Development, 1, 9-11.

[2] Gu Sheng-zu, Liu Wei. (2014). Implementing the New Budget Law urgently needs to improve the local debt governance mechanism. Financial Research, 12, 2-7.

[3] Sun Bo. (2014). Regulating local bonds must be market-oriented and transparent. Economic Guide, 1, 6.

[4] Jia Kang. (2014). Breakthrough of "Budget Law" on local government bonds. China Finance, 22, 21-22.

[5] Yuan Zhi-hui. (2015). Liao Ning debt bids, TianJin debt successfully issued, local debt issuance of the initial market-oriented characteristics. China Economic Weekly, 33, 69.
[6] Wang Li-ying, Sun Yi-fan, Xu Bo-wen. (2014). Study on the risk control in the marketization of local debt in China. China Tianjin.

[7] Zhang Hai-xing. (2001). American and Japanese local government bonds and Its Enlightenment. Research in Finance and Economics, 2, 42-45.

[8] Nakashima K, Saito M.(2009). Credit spreads on corporate bonds and the macroeconomy in Japan. Journal of the Japanese and International Economies, 3, 309-331.

[9] Krugman, P. (1988). Financing vs. Forgiving a Debt Overhang. Journal of Development Economics, 3, 253-268.

[10] Han Li-yan, Zheng Cheng-li, Luo Wen, et al. (2003). Study on the credit risk and bond issue scale of Chinese municipal bonds. Financial Research, 2, 85-94.

[11] David Romer. (2014). Advanced Macroeconomics (Fourth Edition). Shanghai University of Finance and Economics Press.

[12] Fisher L. (1959). Determinants of risk premiums on corporate bonds. The Journal of Political Economy, 217-237.

[13] Yang Ping, Li Bo. (2015). Market-oriented reform of interest rates from the perspective of the issuance of bonds in cities. Southern Finance, 2, 72-82. 